\title{
在来作物の種子保全をめぐる社会学的考察
}

一大和高原の雑穀栽培を事例に一

鶴田格 1$) *$ ・藤原 佑哉 ${ }^{2)}$

\section{The Sociological Dynamics of the In-situ Conservation of Traditional Crop Varieties: A Case Study of Sorghum Production in the Yamato Highlands}

\author{
Tadasu Tsuruta ${ }^{1) *} \&$ Yuya Fujiwara ${ }^{2)}$
}

This paper examines the sociological factors in the in-situ conservation of traditional varieties of sorghum in the Yamato Highlands, Nara prefecture. In village $\mathrm{A}$, red sorghum is still grown to color red bean rice, an auspicious food used in celebrations. A village enterprise dedicated to food processing plays a key role in red sorghum production. Elderly females grow this crop to dye other products bright キーワード : 雑穀栽培, 在来種保存, 大和高原, 食文化

1. はじめに

アワ，キビ，モロコシ(タカキビ) などの雑穀は 日本で古くから栽培され，とくに山間部で重要な食 料源となってきた。しかし雑穀栽培は明治期以降衰 退の一途をたどり，戦後は活とんぞ生産されなくな り各地で消滅していった．近年の雑穀ブームなどに より需要が増え，岩手県など一部では商業栽培がお こなわれているが，一般には従来型の自給的雑穀栽 培はほとんど消滅しているといってよい。

奈良県の大和高原地域でも戦後のコメ生産の進展 により雑穀栽培は㴗とんど姿を消した。ところが, 現在でもごく一部の地域でモロコシ，アワ，キビが 細々と栽培されている。こうした雑穀類は明治期ま ではコメ・ムギとともに主食の一角を担っていたと 思われるが，現在では主食用に栽培されているわけ ではない，モロコシの場合は，穀粒の赤い品種が栽 培され，もっぱら赤飯の着色用にの久使われている. red, the color favored by fellow villagers. In the adjacent village $\mathrm{B}$, which has no enterprises, the same red sorghum is grown by some households but strictly for domestic consumption. In both cases, social relations based on reciprocity within the neighborhood and family are important factors in maintaining this kind of traditional food and crop.

穀粒の皮に含まれる色素を利用して，小豆を使った 通常の赤飯よりも鮮やかな赤色染めることができ るのである。 またアワ，キビに関しては神社の新嘗 祭の神饌用に栽培されている地域がある。

日本の雑穀栽培についてはこれまで主として民族 植物学的あるいは民俗学的な視点からの研究や報告 がなされ，大きな成果をあげてきた（阪本，1988； 増田，2011なぞ). しかし従来の研究に打いては, 雑穀栽培が絶滅寸前にまでに追いつめられたにも関 わらず，なぜこれまで細々とながらも続けられてき たのか，といった点に関して十分な考察がなされて いなかったように思われる。 その原因のひとつは， 雑穀栽培・種子継承に関するこれまでの研究が，村 落内に㗢く社会的な力学にあまり注目してこなかっ たことにあるのではないだろらか、また，筆者の知 る限り, 大和高原の雑穀栽培については, これまで ほとんど報告されていない。

\footnotetext{
1) 近畿大学農学部; Faculty of Agriculture, Kinki University

2) 近畿大学大学院農学研究科; Graduate School of Agriculture, Kinki University

*E-mail: ttsuruta@nara.kindai.ac.jp

(c地域農林経済学会
} 
そこで本論文では，奈良市旧都祁村 A 地区と隣接 する同市旧田原村 B 地区のふたつの地域におけるモ ロコシ栽培の事例をもとに，大和高原の雑穀栽培の 現状について報告するともに，これらの地域で雑縠 種子が現在に至るまで継承されてきた背景について, 社会学的な視点から考察する.

\section{2. 大和高原における雑穀栽培}

奈良県の雑穀栽培・雑穀食に関しては，吉野山地 についての報告はたくさんあるが，大和高原のそれ に関する資料ははなはだ少ない，都祁村の前身であ る旧都介野村および旧針ヶ別所村のそれぞれの村史 には，雑穀の記述はほとんどでてこないわわずかに 『針ヶ別所村史』に「アワとキビを少しずつつくって いた」といら記述があり，また食品の「アカメシ（赤 飯)」の項では「モチ米に小豆を混ぜて蒸す」とあり モロコシには一切言及されていない。この記述が本 論文でとりあげる A 地区での聞き取りに基づくこと を考光ると，モロコシに言及されていないのは奇妙 なことである（針ヶ別所村史編纂委員会編，1969： pp. 379-380；都介野村史編集委員会編，1955)。ま た『都祁村史』に打いても，戦前はコメとオオムギ をまぜる麦飯が主食であり，またコムギやアワを栽 培し粉にして団子にして食べた，といら記述がある のみである。また『都祁村史』で赤飯について述べ た箇所ではモロコシによる着色に関する記述はない (都祁村史編集委員会編， $2005:$ p. 270).同様に『田 原村史』にも雑穀の記述はないに等しいが（田原村 史編集委員会編，1959），1915 年に調査された資料 に基づく『田原村風俗誌』にはトウキビ（モロコシ のこと）を使って赤飯を着色する旨の記述が見られ る (奈良縣添上郡田原村, n.d.).

また奈良県の伝統食を詳細に記述した『聞き書 奈良県の食事』では大和高原の伝統的な食事の代表 的事例として調查地に隣接する山添村のある村の事 例を詳細に報告しているが，雑穀についてはほとん ど触れられていない，ただトゥキビ（モロコシ）に ついて「実を石うすでひいて団子にする」「赤飯をた くときにトウキビの殼で着色をすることがある」と の記述がみられる（藤本注か編，1992：pp. 145, 149）．以上のように関連文献に雑穀に関する記述が ほとんぞでてこないことは，大和高原では明治期に
表 1. 旧田原村における主要穀物生産量（1916 年）

\begin{tabular}{l|l|r}
\hline \hline \multirow{2}{*}{ カテゴリー } & \multicolumn{1}{|c|}{ 内訳 } & 収量 $($ 石 $)$ \\
\hline \multirow{4}{*}{ ユメ類 } & ウルチ米 & $5,327.8$ \\
\cline { 2 - 3 } & モチ米 & 527.3 \\
\cline { 2 - 3 } & 陸稲 & 3.6 \\
\hline \multirow{4}{*}{ ムギ類 } & 裸麦 & 285.8 \\
\cline { 2 - 3 } & 小麦 & 39.1 \\
\cline { 2 - 3 } & 大麦 & 0.2 \\
\hline \multirow{4}{*}{ 雑穀類 } & アワ & 11.9 \\
\cline { 2 - 3 } & キビ & 1.7 \\
\cline { 2 - 3 } & トウキビ（モロコシ） & 9.0 \\
\hline
\end{tabular}

出典 : 奈良縣添上郡田原村編（1917：pp. 205-206).

おいて雑穀はすでに非常にマイナーな存在になって いたことを意味すると考兄られる。

表 1 は旧田原村での 1916 年時点での主要な穀物 生産量をあらわしたものである。これをみると, 調 査地周辺では 20 世紀の初頭ですでに雑穀が（コメ 類・ムギ類に比べ）微々たる量しか生産されていな かったことがうかがえる.

筆者による旧都祁村や隣接する山添村での聞き取 りによれば，雑穀類は戦時中まで主食を補完するた めに食べられていた，高地であるためコメの生産量 が不安定だったといら条件に加えて, 戦時中はコメ やムギなど主要な穀類が供出させられたといら事情 もあったよらである。モロコシやアワ，キビなどを 製粉したあと，(場合によってはモチ米とまぜて）団 子にして食べていた．都祁村ではモロコシ団子とコ ウタケと煮込んだものを「ぬくめ汁」と呼んでいた。

こうした雑穀栽培は戦後急速に廃れていったが, 現在では旧都祁村から（隣接する）旧田原村にかけ て，赤飯の着色にモロコシを使用する地域が残存し ている。 これらの地域では，モロコシは上記の山添 村の場合と同様に「トゥキビ」とよばれている. 赤 飯がつくられるのは，抏もに結婚式，棟上げ式，誕 生日，成人式，入学式，七五三，全快祝いなぞの様 々な祝い事の機会である。とくに大量の赤飯が必要 なのは結婚式などに打㤝る扮祝い返しにおいてであ る。たとえば結婚式のばあい，現在では式場で結婚 式を行った翌日に，祝儀をくれた家々に「拈返し」 として赤飯とタオルケットや鰹節などの引き出物と が配られる。モロコシをつかって赤飯を着色すると 
(小豆の煮汁より) 鮮やかな色がでて, 香りもよい, と村人は考えている。 またアワ，キビに関しては山 添村の少なくとも二つの地区で神社の新嘗祭の神饌 用に現在でも栽培が続けられている ${ }^{1}$. 以下，モロ コシの栽培世帯数が比較的多い旧都祁村 $\mathrm{A}$ 地区なら びに旧田原村 B 地区の事例について検討したい.

\section{3. 旧都祁村 A 地区におけるモロコシ栽培の事例 ${ }^{2}$} （1）モロコシ生産の現状

旧都祁村の A 地区は 70 世帯から成る。そのらち 3 割ほどの世帯で, 現在でも赤飯の着色用にモロコ シが栽培されていると推定される.

A 地区に打けるモロコシ栽培の特徵は, その多く が村内にある農産物加工所兼直売所 S のメンバーに よって栽培されている点である、筆者が $\mathrm{A}$ 地区で 行ったアンケート調査（70 世帯中 38 世帯から回収） により村内のモロコシ栽培者の比率をみると, 直売 所 S のメンバーは 10 名の回答者のらち全員がモロ コシをほぼ毎年欠かさず栽培しているのに対し，A 地区の他の住民（回答者 28 名）のらち 2013 年にモ ロコシを栽培したのは 5 名つまり $18 \%$ にすきない. 非栽培者がモロコシ栽培をやめてからたった年数を みると， 20 年以上 12 名， $11 \sim 20$ 年が 4 名，6〜10 年が 1 名といらららに, 大半が 20 年以上前にモロ コシ栽培をやめていることがわかる．種子について は，栽培者のほとんどは自家採種をしている。また モロコシの栽培や保管, 加工については女性（とく に高齢女性）が中心的な役割を果たしている.

次にモロコシ栽培と赤飯の調達方法の関係につい

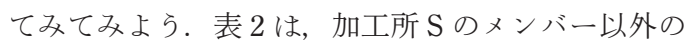
住民に打ける赤飯の調達方法をみたものである. こ れをみると，モロコシ栽培者 5 名に関してはすべて 自宅で赤飯をつくっているのに対して，非栽培者は

表 2. 祝い事に打ける赤飯の調達方法

\begin{tabular}{l|c|c|c}
\hline \hline & $\begin{array}{c}\text { モロコシ } \\
\text { 栽培者 }\end{array}$ & 非栽培者 & 計 \\
\hline 基本的に自宅で作る & 5 & $2^{1)}$ & 7 \\
\hline 自宅でも作るが外注が多い & 0 & 6 & 6 \\
\hline 基本的に外注 & 0 & 13 & 13 \\
\hline 計 & 5 & 21 & 26 \\
\hline
\end{tabular}

出典 : 筆者アンケート調査による.

1）このらち 1 名は赤飯にモロコシを使用しない.
外注する者が多いことがわかる。全体的に現在では 祝い事の際に自宅で赤飯を作るよりも，加工所 S や その他の村内外の事業者に赤飯づくりを外注する傾 向が強くなっていることがらかがえる.

\section{（2）農産物加工所 S の運営}

A 地区の農産物加工所 S は 1998 年ころに設立さ れた．当初は 16 名法どメンバーがいたが，いまは実 質 10 名にまで減少した. メンバーはすべて女性であ り，年齢は 56 歳から 88 歳まで幅があるが， ほとん ぞが 70 歳以上の高齢者である (平均年歯 77 歳). 加工所は直売所を兼衫ており, 毎週土日括よび祝日 に欠かさず加工品を販売している. 月に 2 回ほど奈 良市内の観光案内所などでの出張販売も行っている. また村祭りなど地元の年中行事や定期市，奈良市内 で不定期に行われる各種イベントなどへも出店して いる.

商品の主力は赤飯・山菜おこわ・ちらし寿司・モ チ・草餅・エビ団子の 6 種で. このほか, 各メンバ 一が家でとれた野菜や果実, 自家製の梅干し・漬物 などを包装して随時販売している，商品の值段はす ベて一律に 100 円となっている.

販売当日の早朝，まだ暗いらちからメンバーが加 工所に集まりそれぞれ担当の商品を作る. 朝 7 時ご ろ開店し，加工品に関しては打括敉昼ごろまでに 完売してしまう。村内よりも村外からの客の方が多 い. 近くに複数あるゴルフ場にくる客のほか, 奈良・ 大阪・京都などからわざわざ買いに来る固定客も ある。

赤飯と山菜抏こわなど主要加工品については二人 一組で準備し，材料は担当者が各自で調達する．赤 飯の担当になった場合は, 多くの場合自分で栽培し たモロコシや小豆を使らのである. モチ米について は多くの場合購入している.

表 3 にあるように, 直売所では一回に $4 \sim 5$ 万円, 月に 40 万円程度のらりあげがある。つまり一回に 400～500 品程度の商品が準備されていることになる

表 3. 加工所 S の月別販売収入（2014 年）

\begin{tabular}{c|c|c|c}
\hline & 売上げ計 & 1 日当平均 & 一人当収入 (月) \\
\hline 6 月 & 444,900 & 55,613 & 37,989 \\
\hline 7 月 & 427,360 & 47,484 & 35,681 \\
\hline
\end{tabular}

出典 : 加工所 S 提供資料. 
(らち赤飯のしめる割合は $20 \%$ 程度). 各担当者ごと のらりあげの 1 割を直売所の運営費（電気代，ガス 代など）にまわし，あとの 9 割は各人の収入となる. つまり月 3〜4万円程度のこづかいが各メンバーには いることになる（表 3）。ただしここからモチ米代な ぞ各自が負担する材料費を差し引くと，手元にはい くらも残らないことになる ${ }^{3}$.

赤飯は通常の土日の販売以外でも, 祝い事用にま とまった量の注文をらけることもある。たとえば結 婚式の引き出物として赤飯の大パック（1,000 円） を 30〜50 パックなど大口の注文が入ることがある. そらいらときは複数のメンバーが協力しあって準備 する.

こうした注文に応じるためには一定量のモロコシ 生産が必要である。メンバーたちは加工所のしごと をするよらになってから自家消費分をはるかに超え る量のモロコシを生産するよらになった. こらして 加工所 S の存在がモロコシ生産の強いインセンティ ブとして働いている.

下の表 4 は, 加工所 S のメンバーの 2013 年およ び 2014 年の扮执よそのモロコシ収穫量を個人別に あらわしたものである。これをみると，前年度に生 産したものが余っている場合を除いて，どのメンバ 一も毎年 3～5 升を恒常的に生産していることがうか がえる. これに対して，加工所 Sのメンバー以外の 住民で 5 升以上を収穫した者は皆無であった。非メ ンバーは基本的にモロコシを自家消費すると思われ

表 4. 加工所 Sメンバーのモロコシ生産量

[単位: 升]

\begin{tabular}{c|c|c}
\hline \hline メンバー & 2013 年度 & 2014 年度 \\
\hline $\mathrm{A}$ & 3 & 3 \\
\hline $\mathrm{B}$ & 3 & 3 \\
\hline $\mathrm{C}$ & 5 & 5 \\
\hline $\mathrm{D}$ & 5 & 8 \\
\hline $\mathrm{E}$ & 3 & 5 \\
\hline $\mathrm{F}$ & 3 & 5 \\
\hline $\mathrm{G}$ & 8 & 3 \\
\hline $\mathrm{H}$ & 5 & 5 \\
\hline $\mathrm{I}$ & $-1)$ & 2 \\
\hline $\mathrm{J}$ & $-1)$ & 3 \\
\hline 一人平均 & 4.4 & 4.2 \\
\hline
\end{tabular}

出典 : 筆者調査.

1）前年度のモロコシが余っていたため作付せず.
るが，加工所 S のメンバーにおいては自家消費分よ りも加工所での赤飯作りに投入する部分がずっと大 きい. 赤飯の担当者の手持らのモロコシが不足した 場合はメンバー内で融通しあら。自家消費，加工所 での使用以外に，隣人で家で祝い事があるがモロコ シを栽培していない人に贈与する場合もある.

\section{（3）モロコシと赤飯をめぐる社会関係}

ここではモロコシ生産と赤飯を巡る社会関係につ いて，加工所内部の関係，村民ぞうしの関係，とい ら二つの側面から考えてみたい.

加工所 S は創業以来毎週土日と祝日に営業を続 け，これまで 1 度しか休んだことがないという。ま た A 地区や他の近隣村の村祭りなどで供されるモチ などの特別注文も多く，地域コミュニティに欠かせ ない存在となっている. 高齢女性たちがそこまで奮 闘する理由は何であろらか. 収入そのものは微々た るものであるし，メンバーの発言をみてみると，経 済的な目的以外の動機が女性たちの活動を支えてい るよらに思われる。 つまり加工所 S は, 高歯女性の こづかい稼ぎの場であるといらより，生きがいの場 を提供しているといら側面の方が強いと考光られる のである。メンバーの言葉をそのまま借りると「私 らはボケ防止のつもりでやっている」「あそびのつも りでやっている」といった個人的な動機の表明もあ るが，同時に「店番をしているとなじみの拈客さん が来てくれたりしてやりがいを感じるし，たのしい」 「土日祝日は必ず営業といらので期待してくるお客さ んも多いので頑張って休まずやっている」などの表 現にみられるよらに，顧客との社会的な関係に支え られたやり甲斐，義務感などが加工所継続の大きな 動機となっていることがらかがえる.

またメンバーの多くは A 地区出身であり, 居住地 は A 地区内のひとつの垣内（カイト）とその周辺に 集中している，枑いが本家・分家関係にある者, 血縁関係にある者も含まれるが，そらでないメンバ 一も含まれて扣り，親族的紐帯に基づく集団といら よりは，隣近所にすむ親しい者どらしから成るグル 一プとみた方が正確であると思われる。気の拉けな い仲間だけでやっているので，(仮に誰かが引退する としたら）その娘が継ぐといらことがない限り，よ その人間をメンバーとしてらけいれるのは難しいと いら.こうして親しいメンバーで共同の事業をやる, 
といらことが加工所存続の原動力になって扣り，そ の延長上にモロコシ栽培の存続があると考えられる. 他方で，赤飯のやりとりをめぐる村人間の関係に ついては，「もし陉祝い返しにアズキの赤飯をもらっ たら，口では陉いしいといらが内心がっかりするだ ろら」といら発言に表れているょらに，(とくに高齢 者の間では）モロコシによる着色がのぞましいとい ら一種の規範があるよらに思われる.やりとりされ るのは赤飯そのものだけでなく, 種子もまた贈与さ れる.モロコシを栽培していない世帯が赤飯を作る ことができるのは，ひとつには隣人どらしで穀粒を 融通しあら習慣があるからである 4 . また赤飯をつ くるよらな祝い事の予定はとりあえずないけれども， 家（あるいは地域）で受け継いできたタネを絶やさ ないために（「タネッギのために」）毎年植えている 家もある. こうした行為は家や村の共有財産をめぐ る一種の（今は亡き祖先や将来世代を含めた）世代 を超えた社会的な関係の反映であるともみることも できる、また知り合いから分けてほしいといわれる から, 自分で必要な量以上に生産している人もいる. そこで収穫されたモロコシは（自家で使わないとし ても）隣人の祝い事で使われる可能性がある.

\section{4. 旧田原村 B 地区におけるモロコシ生産 5 （1）モロコシ生産の現状}

次に A 地区のような農産物加工施設・直売所が存 在しない事例として，山を隔てて隣接するB 地区に 打けるケースを検討してみょう，B地区は上下二つ の垣内にわかれて抢り, 上B区が 12 世帯, 下B区 が 8 世帯の計 20 世帯からなっている. このらち 2014 年現在でモロコシを栽培している世帯は上が 7 世帯, 下が 3 世帯となり, 全体では半数の 10 世帯がモ口 コシ生産を続けていることになる.A 地区と同様に, モロコシの栽培や加工には高齢女性が主導権を握っ ているケースが多い.モロコシを栽培していない残 りの 10 世帯のらち少なくとも3 世帯は高齢男性の ひとり暮らし世帯, また他の 2 世帯は $2 \sim 3$ 年前ま でモロコシを栽培していたといらことを考えると， かなりの比率でモロコシ栽培が残存してきたといっ てよい。ただし，A 地区と対照的に，B地区に打け る各世帯のモロコシ生産量は概して少ない. 2014 年 度の生産量が判明した 8 世帯についてはすべて 2 升
未満しか生産していなかった. 赤飯にトウキビを使 い続ける理由については, A 地区と同様に, 鮮やか な赤色がでるから，といら回答が皃とんどであった。

\section{（2）モロコシ・赤飯をめぐる社会関係}

B 地区に打いてもかつては結婚式，棟上げ式など の扣祝い返しとしてモロコシで色づけした赤飯が欠 かせなかった．高齢化・過疎化が進みこうした祝い 事を実施する機会が減少している中，モロコシ生産 が細々と続けられているのはなぜだろらか.

なかには単に食べたいからつくるといら家もある が，多くは誕生日などのちょっとした祝い事に赤飯 を作るためにモロコシ栽培を続けているとみられる. たとえば同居する孫の誕生日に赤飯を炊き，近所に 沶すそ分けをする世帯がある。 また都会に住んでい る孫の誕生日に赤飯を炊き，(近所には分けずに）孫 に届ける世帯もある、扣祝いごとがなくても，たま たま赤飯をたくさん炊いたときなどに，近所に沶す そ分けをするケースもある.

またある女性は，奈良市に住む（田原村出身の） 友人や親せきの家を訪問するさいに，市販の加工品 とちがい100\%モチ米をつかってモロコシによって 色付けした赤飯をつくって扣みやげとして持参する 場合があるという．この地域の出身者には小さいこ ろに食べた赤飯の味を懐かしく思ら人もいて，奈良 市内の市民農園でモロコシを栽培したいといらので, タネを譲ったこともあった.

また興味深いのは村の神事のためにモロコシを栽 培したといら上B区のある家のケースである。この 家では現在はモロコシを栽培していないが，2 年前 に神社祭祀の世話役である「当家 (トウヤ)」の順番 にあたったときにモロコシを栽培した. といらのは 上 B 区では秋祭りの前日（宵宮）の区内住民の会食 の際に赤飯のらえにヒラキサンマを載せたものを供 する，といらしきたりがあったからである ${ }^{6}$. 残念 ながらこの習慣は 2014 年から廃止されたが，それ までは当家がこうした食事を準備しなければならな かった. こらして村の神事での当家としての義務を 果たすためにモロコシを 1 年だけ栽培した. この家 ではまた最近孫娘の結納があり，このときは近所の 人にモロコシを譲ってもらって赤飯を炊いたといら. こうしたタネの贈与は日常的な隣人間のもののやり とりの一環として意識されている. こうして B 地区 
では，家族内，または村内外の社会関係を維持する らえで，モロコシを使った赤飯が一定の役割を果た してきたといえる.

\section{5. 結論}

ここまで二つの村落を事例として，大和高原のモ ロコシ栽培とその利用について検討してきた，A 地 区に敃いては，戦中までは主食の一角を担っていた と思われるモロコシが，現在では赤飯の着色用にの み栽培されている。モモコシを使った赤飯は, 結婚 式，誕生日，棟上げ式などさまざまな祝い事の際に 作られ，香りもよいことから好まれている。 しかし A 地区に打子るモコシ生産は, 単なる自家消費向 けにとどまっているのではない，地区内には農家主 婦を中心とする農産物加工所兼直売所があり, そこ が赤飯生産の拠点となって扣り，また加工所のメン バーを中心にモロコシが多く栽培される傾向がある. 地区内外から祝い事用に大量の赤飯の注文が入るこ とも多く，加工所で働くことは高齢女性に対してあ る種の生きがいを提供している.

A 地区に隣接する B 地区に抢いては，こうした加 工所は存在しないが，いまだに半数の世帯で自家消 費用にモロコシ栽培が続けられている。現在に颃け る赤飯の主要な用途は誕生祝いなどに限られている が，それは家族内や村内の社会関係のみならず，村 内の人間と都会へでていった子ども・孫・友人たち との関係をもつなぐひとつの文化的な道具として機 能していた.

このように大和高原でモロコシ栽培が細々となが らも存続してきたことは, 一定の文化的啫好（モロ コシで着色した赤飯を好むといら）の持続性を示す と同時に，モロコシや赤飯を媒介として形成される 多様な社会関係が種子保全に重要な役割を果たして きたことを示している. その社会関係は様々なレ心゙ ルで観察される。第一に，颃祝い返しの義務や日常 的な贈与交換（赤飯やタネの持すそ分け）にみられ る村人どうしの互酬的・双務的な性質の関係である. 次に，村落共同体の一員としての役割と関わるもの があり，神社の当家としての義務を果たすためにモ ロコシを栽培した事例がこれにあたる。ささらに隣人 間や共同体の義務とは関わらない家族内の社会関係 や，純粋な友人関係の表現手段としてモロコシや赤
飯が利用されるケースもあった。 また加工所 S の事 例は村内外からの顧客と村人の関係が重要な役割を 果たして事業として成功した事例である。こうした 重層的な社会関係のなかでモロコシと赤飯が結節点 として機能し, 結果的に雑穀種子の保全につながっ てきたのだと考えられる。

\section{謝辞}

本論文作成にあたっては，A 地区・B 地区の住民 の方々のほか, 都祁地域扎こし協力隊の加納孝恵氏 ならびに都祁在住の自然農法家國吉賢吾氏の多大な ご協力を得た. 記して謝意を表したい.

\section{注}

1 大和高原に拈ける神饌用の雑穀栽培については, 別稿で詳細 に論じる予定である.

2 本節の記述は，筆者によるA 地区での現地調査（2014 年 4 月〜11月のあいだに 10 回程度実施，住民へのインタビュー と加工所 S での参与観察など) ならびに地区全体を対象に実 施したアンケート調査（2014 年 8 月）によっている.

3 赤飯のケースを考光ると, 仮に小豆とモロコシは自家のもの を使いモチ米だけを購入したとすると，一回の売上（打よそ 37〜38 パックで $3,700 \sim 3,800$ 円）に対してコスト（モチ米 2 升分 $=1,200$ 円と仮定）が少なくとも 3 割程度を占めること になる.

${ }^{4} \mathrm{JA}$ ならんんの都祁経済センターが運営する販売施設では, A 地区拈よび隣接する他地区の生産者 2 名が栽培したモロコシ を販売しているので，近年はここで購入する住民もいる.

5 本節の記述は, 筆者が行った B 地区での悉皆調査（2014 年 11月 15〜17日）によっている.

6 この習慣は同じ B 地区内の下 B 区や隣の A 地区ではみられ ない.

\section{引用文献}

阪本寧男（1988）『雑穀のきた道』日本放送出版協会. 田原村史編集委員会編 (1959)『田原村史』田原地区自治連合会. 都介野村史編集委員会編（1955）『都介野村史』.

都祁村史編集委員会編（2005）『改訂都祁村史 中巻（地理 民俗編)』.

奈良縣添上郡田原村編（1917）『奈良縣添上郡田原村是』. 奈良縣添上郡田原村 (n.d.)『田原村風俗誌』(手稿資料). 針ケ別所村史編纂委員会編（1969）『針ヶ別所村史』. 藤本幸平ほか編（1992）『聞き書 奈良の食事』農山漁村文化 協会.

増田昭子（2011）『雑穀の社会史』吉川弘文館. 